\title{
NA MARGO ADAPTAČNÝCH ŠTÚDIÍ. TEÓRIE, TENDENCIE, FORMY
}

\author{
MARTINA MAŠLÁROVÁ \\ Divadelná fakulta Vysokej školy múzických umení, Bratislava
}

\begin{abstract}
Abstrakt: Príspevok je úvodom k súčasnému teoretickému diskurzu o divadelných adaptáciách. Fenomén uvádzania predlôh nedramatickej povahy v divadle sa rozšíril predovšetkým v druhej polovici 19. storočia, v 20. storočí sa obdobia zvýšeného záujmu o adaptácie cyklicky vracajú. Najnovšiu vlnu inscenovania epiky (a iných predlôh) sme zaznamenali v sezónach ostatnej dekády aj v slovenskom divadle, no teatrológia sa týmto javom zaoberá zatial' skôr okrajovo. Autorka príspevku sa pokúša vytvorit základný obraz o teórii adaptovania v medzinárodnom kontexte aj $\mathrm{v}$ domácom prostredí. Poukazuje na polemiky, ktoré prináša rozmach v tejto sfére výskumu v rámci etablujúceho sa odvetvia adaptačných štúdií. V druhej časti príspevku sa zaoberá otázkou adekvátnej terminológie a uvažuje o diskrepanciách v terminológii navrhovanej rôznymi autormi, s prihliadnutím na historicko-filozofické východiská a iné spoločenskovedné disciplíny (napr. translatológiu). Príspevok nastoluje úvahu o širokom spektre možností, s ktorými teoretici prichádzajú v snahe spresnit pojmový aparát pre uvažovanie o adaptáciách.
\end{abstract}

Klúčové slová: adaptácia, dramatizácia, teória adaptácie, adaptačné štúdiá, terminológia

„Adaptácia je všade " ges tematicky priamo zameranom na fenomén adaptovania a jeho rozmanité podoby a možnosti. V druhej dekáde nového milénia sme aj v slovenskom divadle výrazne pocítili novú vlnu uvádzania pôvodne nedramatických predlôh. Táto prax sa najmä v 20. storočí cyklicky opakovala, tvoriac takmer pravidelnú sínusoidu. Zatial' však tento jav nevzbudil pozornost' teatrológov v takej miere ako iné súčasné trendy, napríklad site-specific, imerzné divadlo, live-cinema a d’alšie. Aj v celosvetovom meradle ostávali reflexie v oblasti (najmä) divadelných adaptácií donedávna roztrúsené v bulletinoch a čiastkových štúdiách. V redakčnom úvode k spomínanému číslu Critical Stages Pavis nepriamo zhrnul stav, v akom sa adaptačný diskurz momentálne nachádza: „Rezignujúc - aspoň zatial’? - na vel’mi problematickú všeobecnú teóriu adaptácie, chceli by sme skromnejšie začat’ pri konkrétnych príkladoch, zmnožiac kontexty, prípadne žánre (divadlo, literatúra, mal'ba), tak ako v mnohých iných prípadových štúdiách. “2

Francúzsky teoretik tu naznačuje niektoré osi, ktoré robia bádanie problematickým. V prvom rade je to enormná šírka záberu, v zásade neobmedzené hranice toho,

${ }^{1}$ PAVIS, P. Special topics: Adaptation. In Critical Stages/Scènes critiques. 2015, č. 12. [online]. [cit. 29. 9. 2019]. Dostupné na internete: http://www.critical-stages.org/12/special-topics-adaptation-2/. Preklad citátov $\mathrm{z}$ anglického a francúzskeho jazyka M. Mašlárová.

${ }^{2}$ Tamže. 
čo možno považovat’ za teritórium adaptácie a čo možno nazývat’ adaptáciou. ${ }^{3} S$ tým súvisí široký diapazón teoretických prístupov a konštantne sa premieňajúci rozbúrený diskurz, v ktorom sa teoretici predháňajú v tom, kto d’alší prispeje k ontologickým, epistemologickým a metodologickým sporom a spochybní už aspoň ako-tak univerzálne prijaté postuláty. A ked’že zjednotenie je zdanlivo v nedohl'adne, sú publikácie, ktoré sa po roku 2000 nevídane rozmnožili, spravidla zborníkmi prípadových štúdií reprezentujúcich niektorý z doterajších prístupov alebo ich l'ubovolné kombinácie. Zaujímavé je tiež sledovat’ špecifiká prístupov v lokálnych kontextoch. Kým v anglofónnom prostredí sa divadlo popri výskume filmových adaptácií dlho opomínalo, francúzski akademici sa teóriou adaptácie zaoberajú síce len odnedávna ${ }^{4}$, avšak bezprostredne sa orientujú aj na vztah literatúry a divadla, respektíve na triádu literatúra - divadlo - film.

\section{Status quo - pohl'ady do minulosti a perspektívy}

Teoretické úvahy o adaptáciách sa objavovali najmä od konca 19. a počas celého 20. storočia. Boli však skôr marginálnou súčastou teórie drámy či iných oblastí, tak ako boli dramatizácie a adaptácie dlho považované za hybridný, okrajový, podozrivý „žáner", napriek tomu, že v moderných dejinách divadla (a obzvlášt filmu) nastal ich vel'ký rozmach. Samozrejme, úvahy o vzţahu medzi dramatickým a epickým sú omnoho staršie, siahajú až k Platónovej Ústave a Aristotelovej Poetike. Na diela antických filozofov v debate o hybridných prienikoch dramatického a epického nadviazali napríklad Johann Wolfgang Goethe a Friedrich Schiller vo svojej korešpondencii. Schiller vyčítal Goethemu, že v románe Wilhelm Meister ${ }^{5}$ používa dramatické a scénické prostriedky, ktoré nie sú nevyhnutné pre plynutie a ciel' románu, čo následne oboch primälo k snahe redefinovat' hranice a atribúty druhov. ${ }^{6}$ Výsledkom ich epištolárnej diskusie bola Goetheho stat' O epickej a dramatickej poézii od Goetheho a Schillera. Medzi epickou a dramatickou poéziou videl Goethe viaceré podobnosti, najmä zobrazovanie spoločných tém a využívanie rovnakých motívov. Za hlavný rozdiel medzi nimi považoval stvárňovanie udalostí ako „dokonale prítomných" v dráme a „dokonale minulých“ v epike, a tiež predstavovanie prostredníctvom „míma, ktorý sa objavuje

\footnotetext{
${ }^{3}$ Ilustratívnym príkladom mnohorakosti prístupov môžu byt práve články publikované v spomínanom čísle Critical Stages - Réžia ako adaptácia; Divadelná teória a pedagogika divadelnej adaptácie Michaila Čechova, Adaptácia ako (znovu)pozeranie, Adaptácia a storytelling v divadle, O zabijaní detí: Grécke tragédie na britských javiskách v roku 2015, Mal'ovat' a premal’ovat' klasické Danwonovo dielo: teatralita a performance Lee Ok Kyounga, Interdisciplinárne úvahy o subžánri súčasnej biografickej drámy: celebrity a fanúšikovia v súčasných javiskových adaptáciách životov slávnych.

${ }^{4}$ Napr. Franco Piva sa v publikácii Il romanzo a teatro ešte v roku 2005 st’ažoval na malé množstvo kritík a reflexií fenoménu uvádzania románov v divadle. Pozri HESSE-WEBER, A. De l'adaptation théâtrale : pour une approche sémiotique et didactique. [dizertačná práca]. Metz : Université Paul Verlaine, 2010, s. 89. Vel’a $\mathrm{v}$ tomto smere napovie aj úvod editorky publikácie Contemporary Approaches to Adaptation in Theatre Kary Reilly z roku 2018: „(...) toto je dosial' jediný zborník, ktorý sa v kontexte adaptačných štúdií zaoberá iba divadelnými adaptáciami." REILLY, K. (ed.) Contemporary Approaches to Adaptation in Theatre. London : Palgrave Macmillan, 2018, s. xxii.

${ }^{5}$ Vol’ná trilógia Wilhelm Meister, najmä prvá čast', Wilhelma Meistera divadelné poslanie, býva označovaná ako Theaterroman, teda divadelný román. Podobným „dramatickým románom“ je napríklad Schillerov Wallenstein.

${ }^{6}$ Correspondence between Goethe and Schiller. From 1794 to 1805. Prel. George-Herbert Calvert. London : Wiley and Putnam, 1845, s. $161-166$.
} 
pred divákmi“ vs. „rapsóda, ktorý je pre publikum neviditel’ný“ ${ }^{7}$ Hoci Schiller teoreticky odmietal svojvolné prestupovanie druhov, uvedomoval si, že tak ako Goethe vo Faustovi, aj on sám sa neraz dopúšta práve takého vnášania epických motívov do dramatickej formy a vice-versa. Na Goetheho východiská neskôr odkazoval i Bertolt Brecht v Malom organone pre divadlo, objasňujúc koncept epického divadla. Francúzsky teoretik Jean-Pierre Sarrazac zase využil figúru rapsóda pre formulovanie vlastnej teórie rapsodizácie drámy ako alternatívy k epizácii drámy či epickému divadlu. ${ }^{8}$

Goetheho so Schillerom by sme v tomto ohlade mohli označit za predchodcov prístupu zohl'adňujúceho špecifiká média, aký uplatnil George Bluestone, ked' sa so svojou, podla viacerých teoretikov prelomovou publikáciou Novels into Film (1957) stal pionierom toho, čo sa medzičasom vyprofilovalo ako adaptačné štúdiá. ${ }^{9}$ Odhliadnuc od skutočnosti, že Bluestone sa v nej venoval filmu, prístup zdôrazňujúci rozdielnost' druhov umenia (médií) a problematickost', eventuálne až nemožnost' ich vydareného a zmysluplného splynutia bol dlho východiskom aj v oblasti divadla.

Prví kritici tejto paradigmy sa objavili už v sedemdesiatych rokoch minulého storočia, ale až koncom milénia sa teória viac-menej úplne preorientovala na intertextuálny a komparatívny prístup, ktorého východiská, postavené na bachtinovsko-kristevovsko-genettovskej línii teórií intertextuality, hutne zhrnula Linda Hutcheon vo svojej Teórii adaptácie (2006, slovenský preklad 2012). Adaptácia prestala byt๋ vnímaná ako izolovaný fenomén a začala sa chápat’ ako dynamický proces vzbudzujúci mnohé kontextové otázky, ktoré teoretici predtým vytesňovali, pretože boli privel'mi zaneprázdnení možnostami prenosu znakov a vlastností z jedného média do druhého.

V novom tisícročí začali niektorí teoretici spochybňovat’ aj intertextualitu ako metodologický rámec pre skúmanie adaptácií. Navrhli uplatňovat’ väčšmi pluralistický prístup, ktorý by mohol oslobodit adaptácie z područia kategórie „vernosti“ (originálu) a únavného mapovania strát a ziskov adaptácií voči predlohám. Podla Roberta Stama mali v minulosti adaptačné štúdiá tendenciu sústredił’ sa viac na subjektívnu otázku kvality adaptácie než na zaujímavejšie otázky teoretického statusu adaptácií a ich analytického záujmu. ${ }^{10}$ Patrick Cattrysse a d’alší v reakcii na normatívny, „na vernost’ zameraný “11 orientovaný prístup navrhli polysystémový alebo polysystematický prístup, orientovaný na potreby, fungovanie a pozíciu ciel'ového, nie východiskového textu. Teoretici ako Stam nasmerovali úvahy o adaptáciách od literárneho diskurzu k východiskám kultúrnych štúdií a analýze socio-historických, ideologických, esteticko-hodnotových rámcov predlohy aj adaptácie.

V ostatných dvoch dekádach sa pozornost’ preniesla z oblasti divadla a filmu na mnohé d’alšie sféry (napr. komiks či videohry) a spoločne s Hutcheonovou sa objavili d’alší teoretici, ktorí sa presviedčajú o tom, že adaptácia je všadeprítomná. Akademici

\footnotetext{
${ }^{7}$ Tamže.

${ }^{8}$ Pozri SARRAZAC, J. P. L'avenir du drame. Paris : Circé, 1999.

${ }^{9} \mathrm{~S}$ týmto predpokladom nesúhlasí napríklad Patrick Cattrysse, tvrdiac, že nemožno ignorovat' mnohé zásadné predchádzajúce práce, ktoré sa venovali filmovým adaptáciám pred Bluestonom a objavili sa v Nemecku už okolo roku 1910, vo Francúzsku v dvadsiatych rokoch 20. storočia a pod. Pozri CATRYSSE, P. Descriptive Adaptation Studies. Epistemological and Methodological Issues. Antwerpy : Garant Publishers, 2014, s. 21.

${ }^{10}$ Pozri STAM, R. Introduction: The Theory and Practice of Adaptation. In STAM, R. - RAENGO, A. (eds.) Literature and Film - A Guide to the Theory and Practice of Adaptation. Oxford : Blackwell, 2005, s. 4.

${ }^{11} \mathrm{~V}$ slovenčine je preklad termínu fidelity-oriented problematický, doslova by znel „vernostne orientovaný".
} 
z rôznych oblastí hladajú nové prístupy k adaptáciám, čo potvrdzujú zborníky ako Adaptation Studies: New Approaches (2010), Redefining Adaptation Studies (2010), Adaptation Studies: New Challenges, New Directions (2013) a d'alšie. Autori berú do úvahy aj faktor diváka ako spolutvorcu adaptácie a často sa hlásia k presvedčeniu, že treba prekonat' chápanie adaptácie ako jednosmerného aktu smerujúceho od originálu k metatextu a že ju treba vnímat’ ako dialogický, obojsmerne pôsobiaci proces, v ktorom každé nové spracovanie nanovo kreuje aj kontext a recepciu pôvodného diela, hoci nemení jeho pôvodnú kvalitu.

Napríklad John Bryant, ktorý vo svojej štúdii rozvíja koncept adaptívnej revízie a adaptovania ako vytvárania fluidného textu, ponúka pohl'ad, v ktorom je dielo súhrnom svojich verzií. Kreativita presahuje individualitu autora a zapája potenciálneho recipienta $\mathrm{v}$ spoločenskej situácii, pričom výsledok revízie treba posudzovat’ v kontexte naprieč druhmi a médiami. Bryant zároveň pripomína, že je mylné hovorit’, že nejaká adaptácia ochudobnila, zdeformovala, nepochopila či zneužila originál, pretože ten procesom adaptovania nad’alej existuje v originálnej podobe, bez akéhokol'vek jej narušenia. ${ }^{12}$

Dôkazom rozmachu v oblasti teoretického zakotvenia adaptácie, po ktorom volala Linda Hutcheon, bolo popri inom založenie britskej Asociácie adaptačných štúdií (The Association of Adaptation Studies, 2006) a Centra pre adaptácie (The Centre for Adaptation), pod ktorého hlavičkou vychádza aj časopis Adaptation. V ostatnej desatročnici zároveň vyšlo množstvo klúčových vstupných a súhrnných publikácií - Translation, Adaptation and Transformation (2012), Descriptive Adaptation Studies: Epistemological and Methodological Issues (2014), The Bloomsbury Introduction to Adaptation Studies (2016), The Oxford Handbook of Adaptation Studies (2017), The Routledge Companion to Adaptation (2018) a d’alšie, ktoré prezrádzajú neustále stúpajúci záujem akademikov o túto oblast’ a popri etablovaných menách aj profiláciu nových bádatel'ov. Ako však pripomína Patrick Cattrysse, napriek existencii týchto „manuálov“ treba mat' na zreteli, že jedným z problémov kníh je ich zdanlivá uzavretost’ či ukončenost’ a že v tomto prípade ide o oblast’ pomerne turbulentného kontinuálneho výskumu. Ten ostáva, ako bolo naznačené v úvode, zatial' bez jednoznačných úsudkov a všeobecne aplikovatel'ných stanovísk, zato s množstvom pochybností, vzájomného spochybňovania sa a kritiky akademikov voči hypotézam ich kolegov. ${ }^{13}$ Pre divadelný kontext je v tomto ohl'ade podnetná aj základná príručka francúzskej teatrologičky Muriel Plana Roman, théâtre, cinéma au XXe siècle: Adaptations, hybridations et dialogue des arts $(2004,2018)$, ktorá je digestom jej rozsiahlej dizertačnej práce.

Zostavovatel'ka publikácie Theatre and Adaptation: Return, Rewrite, Repeat, britská teatrologička, špecialistka na teóriu prekladu a adaptácie Margherita Leara, zvolila iný prístup než jej predchodcovia: knihu tvorí séria rozhovorov s významnými divadelníkmi, ktorí vo svojej praxi nejakým spôsobom využívajú adaptačné techniky. Medzi respondentmi sú o. i. Grzegorz Jarzyna, Ivo van Hove, Romeo Castellucci,

${ }^{12}$ Pozri BRYANT, J. Textual identity and adaptive revision : Editing adaptation as a fluid text. In BRUHN, J. - GJELSVIK, A. - FRISVOLD HANSSEN, E. (eds.) Adaptation Studies: New Challenges, New Directions. London : Bloomsbury Academic, 2013, s. 46 - 67.

${ }^{13}$ Demonštruje to napr. polemika Patricka Cattryssa s Thomasom Leitchom o ich výrazne odlišných prístupoch k adaptáciám. Pozri CATTRYSSE, P. - LEITCH, T. A Dialogue on Adaptation. [online]. [cit. 12. 10. 2019]. Dostupné na internete: https://lfq.salisbury.edu/_issues/46_3/a_dialogue_on_adaptation.html. 
Katie Mitchell, Alvis Hermanis, Simon Stephens, Helgard Haug z Rimini Protokoll, Udaka Michishige a i. Sériu podobne rozmanitých prípadových štúdií, aké prinieslo spomínané číslo Critical Stages, prezentuje aj zborník Contemporary Approaches to Adaptation in Theatre (2016). Na druhej strane, britská teatrologička Frances Babbage upozorňuje na skutočnost', že práve táto širokospektrálnosť môže byt’ aj istým hendikepom, ked’že takto indeterminovaný výskum neberie vždy do úvahy jedinečnost' konkrétnych druhov adaptácií. V úvode k publikácii Adaptation in Contemporary Theatre: Performing Literature (2018) argumentuje, že sa doteraz príliš málo pozornosti venovalo špecifikám adaptácií prózy v divadelnom kontexte, čím čiastočne spochybňuje pluralistický prístup.

\section{Adaptácie v domácom kontexte}

Fenomén divadelných dramatizácií začal v československom teoretickom diskurze intenzívnejšie rezonovat koncom sedemdesiatych rokov a rozvinul sa v osemdesiatych rokoch minulého storočia. Dovtedy sa reflexie o zmysle a úžitku, ale aj $\mathrm{o}$ vhodných prístupoch $\mathrm{k}$ dramatizáciám objavovali najmä $\mathrm{v}$ bulletinoch či recenziách. Už v šest’desiatych rokoch sa však v českom prostredí zaoberal dramatizáciami dramaturg a režisér Miroslav Plešák (diplomová práca Problémy dramatizace epických děl, 1966; štúdia K otázce dramatizování epických děl, 1973), neskôr Václav Königsmark, autor slovníkového hesla dramatizace (Slovník literární teorie, zost. Štěpán Vlašín, 1984) a niekol'kých rozsiahlejších článkov, o. i. Dramatizace jako projev krize i hledání východisek (1977), Krize dramatu, nebo krize kritérií (1981), Místo dramatizací v české dramatice sedmdesátých let a Vztah současného dramatu k literatuře (1982). Ďalším príspevkom do problematiky bola stał Dramatizace v publikácii Rozměry dramatu (1989) literárneho a divadelného vedca Pavla Janouška, ktorý sa dodnes v tejto oblasti pohybuje najmä ako pedagóg.

Na Slovensku vyšli v osemdesiatych rokoch v časopise Slovenské divadlo viaceré štúdie teatrologičky Ol’gy Panovovej, ktorá sa dramatizáciám venovala v diplomovej i dizertačnej práci, a to najmä zo semiotického hladiska ekvivalencie. Jej štúdie Hranice a možnosti žánrovej ekvivalencie v dramatizácii (1985) a O ekvivalentnosti dramatizácie epiky (1986) sa opierali o analýzu Piscatorovej dramatizácie románu Vojna a mier, o dramatizácie Swiftových Gulliverových ciest, Carollových rozprávok o Alici a Exupéryho Malého princa. ${ }^{14}$ Translatologickú prizmu uplatnil v štúdii Epika na javisku: K problematike dramatizácie divadelného diela aj literárny vedec a prekladatel' Branislav Hochel. Na záver článku, ktorého ciel’om bolo analyzovat’ uvedenie McCoyovej dramatizácie Aj kone sa striel'ajú (1985) v trnavskom Divadle pre deti a mládež, Hochel zdôraznil, že chcel „prispiet’ k rekognoskácii problematiky vztahu literatúra - divadlo“, pretože „zmapovat’ súčasný stav tohto vztahu sa nám ukazuje navýsost̉ aktuálne ${ }^{\text {"z }}{ }^{15}$ Napriek tomuto apelu na teoretikov a v tom čase i množiacim sa dramatizáciám sa intenzívnejšie snahy o „mapovanie“" neobjavili.

\footnotetext{
${ }^{14} \mathrm{Na}$ podklade rozboru inscenácií Dostojevského próz na Slovensku sa problematiky dramatizácie dotkli o. i. Pavol Palkovič (1972) a Július Pašteka v analýze Camusovej dramatizácie Besov (1998).

${ }^{15}$ HOCHEL, B. Epika na javisku. K problematike dramatizácie literárneho diela. In Slovenské divadlo, 1986, roč. 34, č. 3, s. 428.
} 
V súčasnosti sa čoraz viac študentov divadelných škôl v záverečných prácach zaoberá konkrétnymi prípadmi dramatizácií v slovenskom divadle. Ojedinele sa objavujú aj snahy o všeobecnejšie teoretické uchopenie problematiky, napríklad príspevok teatrológa a estetika Mirona Pukana Genologické metamorfózy v adaptačných (po)prístupoch niektorých tvorcov na súčasnej slovenskej profesionálnej divadelnej scéne, ktorý zaznel na konferencii Súradnice estetiky, umenia a kultúry III (Prešov 2017). ${ }^{16} \mathrm{O}$ čosi živšie než teatrológia reflektuje na témy adaptačných štúdií domáca filmová veda. Popri rôznych záverečných prácach sa filmovými adaptáciami slovenskej literatúry zaoberali o. i. autori štúdií v zborníku Metamorfózy slovenskej filmovej tvorby (2011). Česká filmová veda $\mathrm{v}$ ostatnom období absorbuje aj zahraničné podnety, a to najmä vd’aka literárnemu historikovi Petrovi Bubeníčkovi. ${ }^{17}$ Naproti tomu, česká teória v oblasti divadla nadväzuje primárne na staršie diela domácej proveniencie a zatial' nezohl'adňuje dianie v zahraničnom kontexte. Dizertačná práca Radky Denemarkovej Sémiotická problematika dramatizací (1997), štúdia Ivy Šulajovej Dramatizace jako teoretický problém (2004) a syntetizujúca dizertačná práca Aleša Merenusa Nárys teorie dramatizací literárních děl (2012) sú ojedinelými súčasnými príspevkami k snahám o ucelenejšie historicko-teoretické uchopenie fenoménu dramatizácií, resp. adaptácií. Zároveň však pribúdajú záverečné práce zaoberajúce sa konkrétnymi prípadmi dramatizácií a adaptácií, na univerzitách sa objavujú teoretické predmety (napr. Divadelní dramatizace divadelních děl pod vedením Pavla Janouška na DAMU v Prahe, Divadelní překlad a adaptace Pavla Drábka na JAMU v Brne) a organizujú sa rôzne hostovania (Thomas Leitch na JAMU) či „,adaptačné workshopy“ (Patrice Pavis na DAMU). Aj z toho je zrejmé, že ide o sféru záujmu, ktorej potenciál rastie i v našom regióne.

\section{Dramatizácia, adaptácia, apropriácia?}

V slovenskom (aj českom) kontexte sa v praxi i v teórii zaužíval v súvislosti s prevodom epickej predlohy do dramatickej podoby (textovej aj performujúcej sa) pojem dramatizácia. S pojmom adaptácia sa stretávame o čosi zriedkavejšie, skôr pri adaptáciách filmových scenárov či spájaní viacerých východiskových textov ${ }^{18}$, a tiež napríklad v recenziách pri opise a analýze konkrétnej javiskovej podoby, výsledku prenosu medzi predlohou a jej realizáciou. Oba termíny sa nám javia dostatočne familiárne, zdanlivo vieme, čo reprezentujú. Presne v jazyku uchopit’ a definovat’ proces a výsledok adaptácie $\mathrm{v}$ zmysle literárneho a inscenačného prevodu je ale o čosi zložitejšie. V štúdiách teoretikov adaptačných štúdií nájdeme množstvo márnych pokusov o zjednotenie terminológie či o nájdenie adekvátnejšieho pojmu. Velavravným príspevkom na túto tému je súpis pojmov vypracovaný akademičkou Marie-Pierre

${ }^{16}$ Príspevok vyšiel v zborníku SÚRADNICE ESTETIKY, UMENIA A KULTÚRY III. Európske estetické myslenie a umelecká tvorba: pramene, metamorfózy a ich relevancia. S. Kopčáková, A. Kvokačka (eds.) Prešov : Prešovská univerzita v Prešove, 2018.

${ }^{17}$ Bubeníčkova monografia Subversive Adaptations (2017) o protirežimných českých filmových adaptáciách vyšla v angličtine vo vydavatel'stve Palgrave Macmillan. Na jeho podnet vyšli aj časopisecky preklady niektorých štúdií zahraničných teoretikov. Filozofická fakulta Masarykovej univerzity, na ktorej Bubeníček vedie predmet Literatura ve filmu, usporiadala v spolupráci s nemeckým partnerom medzinárodnú konferenciu v Nemecku, domáce hostovania zahraničných osobností a i.

${ }^{18}$ Napríklad Danielove Majlingove adaptácie viacerých poviedok Boženy Slančíkovej-Timravy v inscenácii Bál (SND, 2014) či poviedok Roalda Dahla v inscenácii Apartmán v hoteli Bristol (SND, 2016), oboje s označením "na motívy“. 
Lamarque-Rootering, ktoré sa v minulosti zaužívali v súvislosti s recepciou adaptácií. ${ }^{19}$ Celkovo ide o 86 výrazov, z ktorých je 36 podstatných mien a 50 slovies, popri spomínaných napr. derivácia, transformácia, remontáž, derivované dielo, preklad, prenos, variácia, transpozícia, pretvorenie, divadelná imitácia, aranžovanie a d’alšie. Autorka venuje hlbšiu úvahu aj otázke, prečo sa práve pojem adaptácia rozšíril a literatúra ho akceptovala ako najvhodnejší, a zároveň hl'adá možný výraz, ktorý by výstižne obsiahol koncept „divadelnej adaptácie románu“. Zavrhuje neologizmus francúzskej divadelnej historičky Odile Krakovitch roman-pièce (román-hra) a siaha po konkurenčnom pojme roman-drame ${ }^{20}$, ktorý po prvýkrát použil Théophile Gautier ešte v roku 1848, v súvislosti s divadelným uvedením románu Gróf Monte Cristo Alexandra Dumasa st. Zrejme najväčšie úskalie tohto pojmu však spočíva v tom, že pomenúva len výsledok či produkt, eventuálne, ako naznačuje Lamarque-Rooteringová, istý nový, zvrchovaný protožáner, avšak nie činnoste či proces prenosu. Aj iní teoretici a tiež praktici sa pokúsili vytvorił čo najpriliehavejší novotvar. Napríklad francúzsky dramatik a častý adaptátor Pierre Yves Lemieux ponúka slovo transkreácia, ktoré by malo reprezentovat' „tvorbu umelca prostredníctvom tvorby iného umelca". ${ }^{21}$

Linda Hutcheon tieto snahy lakonicky komentuje vo svojej Teórii adaptácie: „Kvôli komplexnosti toho, čo sa môže adaptovat', a prostriedkov adaptácie, sa l'udia pokúšajú vytvorit’ nové slová, aby nahradili mätúcu jednoduchost’ slova ,adaptácia’." ${ }^{22}$ Zároveň upozorňuje na ambivalentnost' pojmu, ktorý sa používa pre pomenovanie procesu i jeho výsledku (produktu), z čoho vyplývajú d’alšie úskalia ako dôsledok snahy nájst’ nejakú všeobjímajúcu definíciu. Aj preto lingvista a divadelný teoretik Gérard-Denis Farcy ${ }^{23}$ navrhuje rozlišovat’ adaptáciu-produkciu a adaptáciu-produkt. Filmový vedec Timothy Corrigan rozširuje dvojakú perspektívu ešte o tretiu možnost:: „DEFINÍCIE adaptácie majú tendenciu pohybovat’ sa medzi tromi perspektívami. V zmysle procesu adaptácia často opisuje, ako sa jedna alebo viac entít rekonfiguruje, respektíve prispôsobí vo vztahu k jednému či viacerým iným textom alebo objektom. V zmysle produktu môže adaptácia značit’ entitu, ktorá je výsledkom tohto zapojenia, alebo je syntetizovaným výsledkom vztahu medzi dvoma alebo viacerými činnostami. (...) Novšie definície priniesli tretiu perspektívu: adaptáciu ako akt recepcie, v ktorom sa čítanie alebo sledovanie diela aktívne adaptuje ako špecifická forma pôžitku a porozumenia. Z tohto uhla môžu čitatelia pochopit’, že rôzne diela fungujú

${ }^{19}$ Pozri LAMARQUE-ROOTERING, M. P. Les adaptations théâtrales de romans français au XIXe siècle. [dizertačná práca]. Paris : Université Sorbonne nouvelle-Paris 3, 2007, s. 338 - 342. Podobný exkurz realizuje aj Márta Minier, ked’ vyratúva rôzne termíny/prístupy spojené s teóriou adaptácie a zároveň s teóriou prekladu - preklad, apropriácia, verzia, transpozícia, transformácia, doplnok, parafráza, paródia, alúzia, intertextualita, pastiš, satira, duplikácia, opakovanie, revízia, inverzia, prepis, repozícia, reinvencia, reimaginácia, uspôsobenie, permutácia, rejuvenizácia, ozvena, transfigurácia, transplantácia, rekontextualizácia a d’alšie. Pozri MINIER, M. Definitions, Dyads, Triads and Other Points of Connection in Translation and Adaptation Discourse. In KREBS K. Translation and Adaptation in Theatre and Film. New York : Routledge, 2014, s. 15 - 17.

${ }^{20}$ Až manifestačne na záver kapitoly uvádza autorka boldom zvýraznenú vetu: „Zjednotený pojem romándráma sa stáva symbiotickým označujúcim hybridného autonómneho označovaného, otvárajúc nový literárny priestor, produktívny, novátorský a hodný výskumu. “ LAMARQUE-ROOTERING, M. P. Les adaptations théâtrales de romans français au XIXe siècle, s. 353.

${ }^{21}$ LEMIEUX, P. Y. Du livre à la scène. In JEU, 2018, roč. 43, č. 166, s. 27.

${ }^{22}$ HUTCHEON, L. Teória adaptácie. Brno : JAMU, 2012, s. 31 - 38.

${ }^{23}$ FARCY G.-D. L'adaptation dans tous ses états. In Poétique, 1993, č. 93, s. 388. 
odlišne pre rôznych čitatel’ov v závislosti od ich zázemia, zatial' čo komunita môže asimilovat’ alebo neasimilovat’ nového člena tejto kultúry rôznymi spôsobmi. V rámci tohto tripartitného rámca špecifickejšie a konkrétnejšie postupy a teórie formovali tradičnú i súčasnú prax adaptácie, v ktorej, ako v celej histórii, sú definície adaptácií vždy o readaptovaní iných definícií.“ ${ }^{24}$

\section{Rôzne varianty dramatizácie}

Predpoklad, že používanie dvojice pojmov dramatizácia - adaptácia by mohlo situáciu zjednodušit', sa tiež nepotvrdil. V prvom rade preto, že oba výrazy sa používajú nejednotne, často ako zamenitel'né varianty. Zároveň sa ich sémantické pole líši v závislosti od jazykového prostredia (germánske, angloamerické, románske,...), aj od oblasti činností, v ktorých sa používajú ${ }^{25}$. A napokon, aj tu existuje rad d’alších slov, ktoré sa za istých okolností môžu zdat’ adekvátnejšie, presnejšie, jednoznačnejšie pre daný prípad, zároveň je však obmedzené ich všeobecné uplatnenie. Práve pre túto heterogénnost' mnohí zahraniční teoretici v súčasnosti upúštajú od urputných snáh o klasifikáciu či jasnejšie vymedzenie termínov. ${ }^{26}$

Naopak, v českej teatrológii, resp. literárnej teórii sa po roku 2000 objavilo niekol'ko prác usilujúcich sa v rámci výskumu problematiky dramatizácií aj o vytvorenie akejsi sémantickej mapy. Jednotlivé definície podla ich autorov závisia najmä od úrovne vzt’ahu medzi literatúrou a divadlom. Iva Šulajová pripomína, že rôzne výklady pojmu dramatizácia sa zhodujú na tom, že ide o metatext ${ }^{27}$, d’alšie chápanie je však omnoho menej jednoznačné: „V súvislosti s dramatizovaním rôznych druhov pôvodne nedramatických predlôh sa stretávame s mnohými rozmanitými formami metatextov, ktoré bývajú tiež nejednotne terminologicky označované. Najbežnejšie sú zrejme dva termíny: dramatizácia a divadelná adaptácia. Oba však nemajú v divadelnej teórii dosial ustálené používanie, hlavným dôvodom je práve široká škála prístupov k prepisu z jedného literárneho druhu do druhého a následne i do iného druhu umeleckého - pevnejšia či vol'nejšia väzba na predlohu, ,jednorazovét využitie novo vzniknutého textu v konkrétnej inscenácii, alebo naopak pôvodná dráma napísaná iba na motívy predlohy atd." ${ }^{28}$

Vychádzajúc z hesla Václava Königsmarka v Slovníku literární teorie a z Poetického slovníka Tibora Žilku chápe Šulajová dramatizáciu ako prevod medzi literárnymi druhmi (napr. na základe románu vzniká dramatický text), ktorého výsledkom je literárne dielo - samostatný žáner drámy. Adaptáciu ${ }^{29}$ vníma ako bližšiu prevodu

${ }^{24}$ CORRIGAN, T. Defining Adaptation. In LEITCH, T. (ed.) The Oxford Handbook of Adaptation Studies. New York : Oxford University Press, 2017, s. 23.

${ }^{25}$ Popri umeleckej sfére sa pojem dramatizácia často používa napríklad v pedagogike.

${ }^{26}$ Pozri LEARA, M. Theatre and adaptation: return, rewrite, repeat. London : Bloomsbury Methuen Drama, 2014 , s. 5 .

${ }^{27}$ Terminológiu, ktorá sa v Československu v súvislosti s intertextualitou objavila v sedemdesiatych rokoch 20. storočia a ktorej ústrednými pojmami sú prototext a metatext, však reprezentant tzv. Nitrianskej školy Tibor Žilka spochybnil ako nekorešpondujúcu so západnými trendmi. Pozri ŽILKA, T. Text a posttext. Nitra : Univerzita Konštantína Filozofa v Nitre, 2011, s. 7 - 8.

${ }_{28}$ ŠULAJOVÁ, I. Dramatizace jako teoretický problém. In Divadelní revue, 2004, roč. 15, č. 4, s. 47. Preklad z českého jazyka M. Mašlárová.

${ }_{29}$ Šulajová uvádza, že termín adaptácia prenikol do divadelnej terminológie z filmovej vedy, skôr je však prebratý z inojazyčného prostredia, ked’že napr. vo francúzskych výkladových slovníkoch sa v zmysle 
medzi umeleckými druhmi (napr. inscenácia na základe filmového diela), pričom cielom adaptácie nie je vznik samostatne fungujúceho literárneho diela a literárna hodnota textu je v takom prípade sekundárna. Aleš Merenus pre obdobné rozlíšenie používa pojmy „dramatizácia v užšom zmysle“ (textová) a „dramatizácia v širšom zmysle“ (inscenačná) a konštatuje pritom, že v prevažnej väčšine prípadov sa dramatizácia v užšom zmysle slova stáva súčastou dramatizácie v širšom zmysle slova. Zároveň navrhuje delit’ dramatizácie podla troch línií: (1) podla štruktúrnej/funkčnej osi na „dramatizácie: literárne" a „dramatizácie: divadelné“; (2) podl’a vztahu k predlohe na „dramatizácie: imitácie“ a „dramatizácie: inovácie“; (3) podl’a pragmatických činitel’ov, ktoré zhŕňa v jednej kategórii, tzv. dramatizácie z hladiska externých faktorov - sem patria napr. vzt’ah dramatizátora k predlohe, jeho pozícia v literárnom a divadelnom umení, konkrétna väzba s divadelným súborom, poetika divadla a pod. ${ }^{30}$

Iní autori uprednostňujú hierarchizáciu, ktorá adaptáciu chápe ako zastrešujúci pojem, integrujúci v sebe dvojicu podmnožín - dramatizácie a divadelné adaptácie, pričom kategória dramatizácie sa ešte delí na literárne dramatizácie a divadelné dramatizácie. Patrice Pavis vo svojom Divadelnom slovníku (alebo minimálne jeho slovenské prekladatel'ky Elena Flašková a Soňa Šimková) zas používa pojmy viac-menej ekvivalentne, ked’ dramatizáciu definuje ako „adaptáciu textu (epického alebo poetického) na dramatický text alebo na scénický materiál“31 a pri hesle adaptácia hovorí o divadelnej adaptácii ako synonyme dramatizácie. ${ }^{32}$

Vo francúzštine má pojem dramatizácia od šesṫdesiatych rokov minulého storočia ešte iné konotácie vo filozofickom diskurze. Postštrukturalista Gilles Deleuze ho použil v rámci pomerne zložitého konceptu metódy dramatizácie, ktorý predstavil v prednáške pre Société Française de Philosophie v roku $1967 .{ }^{33}$ Dramatizáciou v nej označil isté dynamické časopriestorové determinácie prenikajúce do organizácie filozofického myslenia a d’alších systémov, ktoré nie sú primárne divadelné. V jeho koncepte pojem dráma svojím spôsobom substituuje iné logos, čím sa navodzuje dramatický účinok daného logos (napríklad v psychoanalýze a iných oblastiach humanitných vied, alebo v každodennom živote pri používaní pojmov ako scéna, situácia, dráma), a zároveň implikuje usporiadanie priestoru/javov v priestore. To je len jeden z príkladov poukazujúcich na mnohoznačnost’ slova.

$\mathrm{V}$ angloamerickom prostredí rozlišovanie medzi pojmami dramatizácia a adaptácia súviselo $\mathrm{v}$ minulosti $\mathrm{s}$ mierou autorského vkladu a originality spracovania, v súčasnosti sa však tento rozdiel stiera. Podla britského literárneho vedca Michaela Inghama sa v slovníku kedysi jasne oddelovali adaptácie, ktoré boli prejavom autonómnej tvorivosti (napr. Piscatorove a Brechtove adaptácie Dobrého vojaka Švejka), od „bežných“ dramatizácií, ktoré smerovali len k dôslednému prenosu predlohy (napr.

\footnotetext{
pretvorenia románu do divadelnej podoby po prvý raz objavil už v roku 1899 a ako modifikačný proces prenosu z jedného diela do druhého v širšom zmysle sa ustálil v tridsiatych rokoch minulého storočia. Niektoré súčasné príručky, napr. český Teatrologický slovník (2004), však pojem adaptácia nezahŕňajú.

${ }^{30}$ Pozri MERENUS, A. Geneze a vývojové proměny české dramatizační praxe ve 20. a 21. století pohledem konceptu tří os". In Bohemica litteraria, 2013, roč. 16, č. 1, s. $118-120$.

${ }^{31}$ PAVIS, P. Divadelný slovník. Bratislava : Divadelný ústav, 2004, s. 141.

32 Ďalšou nuansou odhal'ujúcou odlišnost’ slovenskej verzie napríklad od anglickej jazykovej mutácie Pavisovho slovníka, je doplnenie hesla aj o pojem úprava - tiež u nás zaužívaný v súvislosti s adaptáciami. Pozri PAVIS, P. Divadelný slovník, s. 26.

${ }^{33}$ Pozri DELEUZE, G. La méthode de dramatisation. In L'Tle déserte. (ed. David Lapoujade). Paris : Éditions de minuit, 2002, s. $131-163$.
} 
dramatizácie detektívok Agathy Christie). ${ }^{34} \mathrm{~V}$ praxi sa dnes ale oba termíny používajú synonymicky a je výrazná tendencia nazývat’ akýkolvek transmediálny prenos adaptáciou. Podla Inghama táto prax vyústila do presvedčenia, že všetky javiskové verzie prozaických predlôh chcú inscenovat’ samotné dielo, a nie hru, pre ktorú by napr. román či novela boli iba zdrojom. Zároveň to podla neho nedostatočne odráža rozdiely medzi dielami, ktoré síce vytvárajú paralely so zdrojovým textom, ale realizujú jeho vlastné čítanie, a tými, ktoré sú len „vizuálnym ekvivalentom audioknihy ${ }^{\prime 35}$.

Muriel Plana prispôsobuje delenie adaptácií historickým premenám francúzskej praxe. Prvým variantom sú „,klasické“ adaptácie-dramatizácie, ktoré nazýva „tradičnými adaptáciami“ (ich východiskom je epická predloha a výsledkom divadelná hra alebo filmový scenár, dej je reprodukovaný čo najvernejšie). Časovo ich v divadelnom kontexte situuje predovšetkým po obdobie naturalizmu, pričom tvrdí, že dominantným princípom adaptácie ostáva dramatizácia najmä vo filme. Druhým, menej verným spôsobom adaptácie je podl’a nej adaptácia-dramatizácia-transpozícia, ktorá zásadnejšie modifikuje predlohu. Podla Planovej je tento typ často negatívne prijímaný práve pre „zradu“ vykonanú na pôvodnom diele, pričom výstižne pomenúva paradox oboch typov adaptácie: „Zatial’ čo tradičnej adaptácii sa často vyčíta, že je servilná alebo zbytočná, tak adaptácia-transpozícia, kreatívnejšia, vol’nejšia, býva občas obviňovaná z toho, že v podstate iba jednoducho anektuje texty. ${ }^{\text {" }} 6$

Pokial ide o samotných divadelných praktikov a ich príspevok do diskusie, Margherita Leara uvádza, že autori a respondenti rozhovorov zastúpení v jej knihe (pozri vyššie) chápu termín adaptácia rôzne a nahliadajú naň bez striktného pridŕžania sa jednotiacej definície. ${ }^{37}$ Rozpory medzi akademikmi a praktikmi podla nej spočívajú popri inom v tom, že tí druhí často popri adaptácii siahajú aj po termíne apropriácia, ktorého atribúty podrobne analyzovala v publikácii Adaptation and Appropriation (2005) anglistka Julie Sanders. Medzi nuansy apropriačných prístupov radí teoretička napríklad verziu, variáciu, interpretáciu, nadviazanie (continuation), transformáciu, imitáciu, pastiš, paródiu, podvrh, travestiu, revaluáciu, revíziu, prepis (rewriting). ${ }^{38}$ Nevýhodou podobných delení je na jednej strane ich nestabilita (niektoré z konceptov sú všeobecne zaužívané, iné sú len súčastou tej-ktorej teórie) a na druhej strane fakt, že niekedy vel'mi tenká hranica medzi definíciami jednotlivých stratégií stavia potenciálneho bádatel’a pred začarovaný kruh zložitého vyhodnocovania, s ktorou z nich má momentálne do činenia.

To potvrdzuje aj Margherita Leara, podla ktorej apropriácia implikuje nižšiu mieru vernosti pôvodnej predlohe. Ona sama ju však vníma ako synonymum adaptácie, pretože je podla nej príliš problematické vytvorit’ deliacu líniu medzi „vernou adaptáciou“ a "nie vernou apropriáciou“ („napokon, vernou alebo nie vernou čomu?",

${ }^{34}$ Pozri INGHAM, M. A. The Prose Fiction Stage Adaptation As Social Allegory In Contemporary British Drama: Staging Fictions. Lampeter : Edwin Mellen Press, s. 22 - 23.

${ }^{35}$ Tamže.

${ }^{36}$ Ďalšími variantmi, ktoré Plana uvádza, sú adaptácia-neadaptácia, scénický prepis, divadlo-rozprávanie a montáž-adaptácia. Pozri PLANA, M. Roman, théâtre, cinéma. Adaptations, hybridations et dialogues des arts. Rosny-sous-bois : Bréal, 2004, s. 31 - 36.

${ }^{37}$ Pozri LEARA, M. Theatre and Adaptation: Return, Rewrite, Repeat. London : Bloomsbury Methuen Drama, 2014, s. $4-10$.

${ }^{38}$ SANDERS, J. Adaptation and Appropriation. New York - London : Routledge, 2005, s. 3. 
pýta sa). ${ }^{39}$ Preto navrhuje systém, ktorý namiesto stupňa intertextovosti berie do úvahy druhy vzt’ahov medzi adaptovaným dielom a adaptáciou. Odvolávajúc sa na delenie Romana Jakobsona a bachtinovsko-kristevovsko-genettovskú líniu intertextuality, rozlišuje popri intra- a interlingválnej adaptácii aj delenie na d’alšie stupne: intra- a intertemporálnu, intra- a interkultúrnu, intra- a intermediálnu, intra- a intergenerickú (vnútro- a medzidruhovú), intra- a interideologickú adaptáciu, domestikáciu a foreignizáciu (úpravu s ohl'adom na familiárnost' pre ciel’ového recipienta).

Na základe tohto výpočtu je zjavné, že jestvuje celá siet', priam labyrint možností kategorizácie adaptovaných diel a uvažovania o procesoch adaptovania, pričom však treba mat’ na zreteli, že tieto kategórie nemusia nijako korešpondovat' s intenciami tvorcov. Pojmy i výklady by zrejme (v jednej línii s Corriganovou premisou) bolo potrebné vždy nanovo prehodnotit podla konkrétneho prípadu, v ktorom by terminológia mala korešpondovat’ s východiskami umeleckej osobnosti či požiadavkami divadelného organizmu, a zároveň odrážat’ zmeny prebiehajúce súbežne s historickým vývojom divadla ako takého. V tejto fáze sa zrejme musíme spoliehat na univerzálnost’ a - povedané spolu s Hutcheonovou - istú banálnost’ všeobjímajúcej adaptácie či dramatizácie.

\section{REFLECTION OF ADAPTATION STUDIES. THEORIES, TENDENCIES, FORMS}

\section{Martina MAŠLÁROVÁ}

The paper is an introduction to contemporary theoretical discourse about theatre adaptations. The phenomenon of staging texts and other sources of non-dramatic nature in the theatre developed mainly in the second half of the 19th century and in the 20th century, periods of increased interest in adaptation are cyclically recurring. The latest wave of staging of epic texts (and other) could have been observed in the seasons of the past decade in the Slovak theatre as well, but the theatrology has been dealing with this phenomenon rather marginally. The author attempts to create a basic landscape of the theory of adaptation in the international context, as well as in the domestic environment and points out the controversies that are being brought up in this area of research within the establishing field of adaptation studies. The second part of the paper deals with the question of adequate terminology and considers discrepancies in terminology proposed by various authors within the context of historical-philosophical bases and other social sciences (e.g. translatology). The paper presents a wide range of possibilities that theorists have come up with in order to clarify the conceptual apparatus for thinking about adaptations.

Text vznikol v rámci doktorandského štúdia na Divadelnej fakulte Vysokej školy múzických umení v Bratislave, školitel'ka Soňa Šimková.

${ }^{39}$ LEARA, M. Theatre and Adaptation: Return, Rewrite, Repeat, s. 5. 


\section{LITERATÚRA}

BABBAGE, Frances. Adaptation in Contemporary Theatre: Performing Literature. London : Bloomsbury Methuen Drama, 2018. 280 s. ISBN 978-1-4725-3052-3.

BRUHN, Jorgen - GJELSVIK, Anne - FRISVOLD HANSSEN, Eirik (eds.) Adaptation Studies: New Challenges, New Directions. London : Bloomsbury Academic, 2013. 304 s. ISBN 978-14411-0647-6.

CATRYSSE, Patrick. Descriptive Adaptation Studies. Epistemological and Methodological Issues. Antverpy : Garant Publishers, 2014. 364 s. ISBN 978-9-0441-3129-1.

CATTRYSSE, Patrick - LEITCH, Thomas. A Dialogue on Adaptation. [online]. Dostupné na internete: https://lfq.salisbury.edu/_issues/46_3/a_dialogue_on_adaptation.html.

Correspondence between Schiller and Goethe from 1974 to 1805. Prel. George H. Calvert. New York - London : WILEY AND PUTNAM, 1845. $414 \mathrm{~s}$.

DELEUZE, Gilles. La méthode de dramatisation. In L'Ile déserte et autres textes. (ed. David Lapoujade). Paris : Éditions de minuit, 2002, s. 131 - 163. ISBN 978-2-7073-1761-2.

FARCY Gérard-Denis. L'adaptation dans tous ses états. In Poétique, 1993, č. 93, s. 387 - 414. ISSN $1245-1274$.

HESSE-WEBER, Armelle. De l'adaptation théâtrale : pour une approche sémiotique et didactique. [dizertačná práca]. Metz : Université de Metz, 2010. 997 s.

HOCHEL, Branislav. Epika na javisku. K problematike dramatizácie literárneho diela. In Slovenské divadlo, 1986, roč. 34, č. 3, s. 419 - 428. ISSN 0037-699X.

HUTCHEON, Linda. Teória adaptácie. Brno : JAMU, 2012. 246 s. ISBN 978-8074-60-02-72.

INGHAM, Michael Anthony. The Prose Fiction Stage Adaptation As Social Allegory In Contemporary British Drama: Staging Fictions. Lampeter : Edwin Mellen Press, 2004. 373 s. ISBN 97807-7346-356-1.

JANOUŠEK, Pavel. Rozměry dramatu. Praha : Panorama, 1989. 308 s. ISBN 80-7038-091-8.

KREBS, Katja. Translation and Adaptation in Theatre and Film. New York : Routledge, 2014. $224 \mathrm{~s}$. ISBN 978-0-415-2968-7.

LAMARQUE-ROOTERING, Marie-Pierre. Les adaptations théâtrales de romans français au XIXe siècle. [dizertačná práca]. Paris : Université Sorbonne nouvelle-Paris 3, 2007. $486 \mathrm{~s}$.

LEARA, Margherita. Theatre and Adaptation: Return, Rewrite, Repeat. London : Bloomsbury Methuen Drama, 2014. 284 s. ISBN 978-1-4725-3316-6.

LEITCH, Thomas (ed.) The Oxford Handbook of Adaptation Studies. New York : Oxford University Press, 2017. 784 s. ISBN 978-0-19-933100-0.

LEMIEUX, Pierre-Yves. Du livre à la scène. In JEU, 2018, roč. 43, č. 166, s. 26 - 30. ISSN 0382-0335.

MERENUS, Aleš. Geneze a vývojové proměny české dramatizační praxe ve 20. a 21. století pohledem konceptu tři os. In Bohemica litteraria, 2013, roč. 16, č. 1, s. 113 - 133. ISSN 1213-2144.

MERENUS, Aleš. Nárys teorie dramatizací literárních děl. [dizertačná práca]. Brno : Masarykova univerzita, 2012. $187 \mathrm{~s}$.

MERENUS, Aleš. Př́běh a dramatizace. In Podoby a funkce př́běhu: pokus o interdisciplinární debatu. Milena Vojtková (red.). Praha : Ústav pro českou literaturu AV ČR, 2011, s. 20 - 32. [online]. Dostupné na internete: http://www.ucl.cas.cz/slk/data/2010/sbornik/5.pdf.

PANOVOVÁ, Ol'ga. O ekvivalentnosti dramatizácie epiky. In Slovenské divadlo, 1986, roč. 34, č. 3, s. 286 - 307. ISSN 0037-699X.

PAVIS, Patrice. Divadelný slovník. Bratislava : Divadelný ústav, 2004. 542 s. ISBN 80-889-8724-5.

PAVIS, Patrice. Special topics: Adaptation. In Critical Stages/Scènes critiques, 2015, č. 12. [online]. Dostupné na internete: http://www.critical-stages.org/12/special-topics-adaptation-2/. ISSN 2409-7411.

PLANA, Muriel. Roman, théâtre, cinéma. Adaptations, Hybridations et Dialogues des Arts. Rosny-sous-bois : Bréal, 2004. 256 s. ISBN 2-7495-0263-2. 
PLANA, Muriel. La relation roman-théâtre des lumières à nos jours. Théorie, études de textes. [dizertačná práca]. Paris : Université de la Sorbonne Nouvelle, 1999. 599 s.

REILLY, Kara (ed.) Contemporary Approaches to Adaptation in Theatre. London : Palgrave Macmillan, 2018. 357 s. ISBN 978-1-137-59783-0.

SANDERS, Julie. Adaptation and Appropriation. New York - London : Routledge, 2005. $200 \mathrm{~s}$. ISBN 978-1-138-82899-5.

SARRAZAC, Jean-Pierre. L'avenir du drame. Paris : Circé, 1999. 210 s. ISBN 978-2-842-42072-7.

SARRAZAC, Jean-Pierre. Théâtres intimes. Arles : Actes Sud. 166 s. ISBN 978-2-868-69299-3.

STAM, Robert - RAENGO, Alexandra. (eds.) Literature and Film - A Guide to the Theory and Practice of Adaptation. Oxford : Blackwell, 2005. 376 s. ISBN 978-0-631-23055-7.

ŠULAJOVÁ, Iva. Dramatizace jako teoretický problém. In Divadelní revue, 2004, roč. 15, č. 4, s. 46 - 61. ISSN 0862-5409.

ŽILKA, Tibor. Text a posttext. 2. vyd. Nitra : Univerzita Konštantína Filozofa v Nitre, 2011. $161 \mathrm{~s}$. ISBN 978-80-8094-878-8.

\author{
Martina Mašlárová \\ Katedra divadelných štúdií DF VŠMU \\ Zochova 1 \\ 81301 Bratislava \\ e-mail: maslarova@vsmu.sk
}

